\title{
A influência da televisão na educação*
}

\author{
Fabricio Antonio Raupp ${ }^{l}$ \\ Universidade do Sul de Santa Catarina \\ Ana Carolina Salerno Del Menezzi Tessari ${ }^{2}$ \\ Universidade do Vale do Itajaí \\ Maria José Baldessar ${ }^{3}$ \\ Fernando José Spanhol ${ }^{4}$ \\ Universidade Federal de Santa Catarina
}

O presente artigo faz uma abordagem genérica dos principais meios de comunicação, ou mídia, para contextualizar o crescente papel da televisão como agente de informação e manipulação da sociedade contemporânea. A partir daí, são apresentadas as principais vertentes do processo de transmissão de informações presentes nesse tipo de comunicação. Com base nas principais características do uso da televisão, é descrita a forma como a população interage com a informação recebida. Em paralelo, são descritas as bases presentes no processo de educação em geral, e nos processos alternativos, em particular. Por fim, faz-se uma análise da utilização da mídia, especificamente a televisão, como ferramenta educacional, destacando suas potencialidades, suas limitações e os cuidados necessários para que esse uso atinja, de forma efetiva, o seu propósito.
This article approaches in a general way the main means of communication, or media, to contextualize the growing role of television as a means of information and manipulation of society nowadays. From this standpoint are presented the main streams to convey information in this means of communication. Considering the main features of television usage, a description is made on the way population interacts with the supplied information. Besides this, the fundaments of educational process in general, and alternative processes in particular, are described. Finally is made an analysis of media application, particularly television, as an educational tool, highlighting its potenciality, limitations and the cautions necessary for effectively reaching the goals intended.

\footnotetext{
* The influence of television on education

${ }^{1}$ Psicologia - UNISUL, Especialização em Gestão e Marketing - UFSC. Endereço para correspondências: Rua Professora Leonor de Barros, 39; Pantanal, Florianópolis, SC 88040-240 (contato@raupp.psc.br).

${ }^{2}$ Medicina - UNIVALI, Residência Médica em Pediatria - HIJG.

${ }^{3}$ Comunicação Social Jornalismo - UFSC, Doutorado em Ciências da Comunicação - UFSC.

${ }^{4}$ Pedagogia - UNOCHAPECO, Doutorado em Engenharia de Produção - UFSC.
} 
Palavras-chave: Educação - Televisão - Mídia - Informação
Keywords: Education - Television Media - Information

\section{Introdução}

$\mathrm{M}$ uitas eras forjaram a evolução da sociedade até o estágio como a conhecemos hoje. Em cada uma delas, prevaleceu algum tipo de inovação cultural, social ou tecnológica, em variadas combinações. É correto afirmar que a época atual é a era da informação. E essa é uma constatação inquestionável. Basta observar a rapidez com que as informações transitam pelo planeta e a agilidade que essas mesmas informações são agregadas aos valores e costumes.

Os meios com que essas informações são disseminadas têm evoluído num ritmo proporcionalmente veloz. Ao rádio e à imprensa escrita, que permanecem preenchendo seu espaço, aliou-se a televisão ao longo do último século e, nos últimos vinte anos, a internet veio se somar aos anteriores.

As transformações vividas pela sociedade criam grandes necessidades de adequação das pessoas nela inseridas. Por isso, a educação como ferramenta de desenvolvimento, passou a ocupar cada vez mais espaço em todas as camadas sociais. Não há como sustentar o rápido desenvolvimento, que se apresenta como necessário e inevitável, sem uma sólida base educacional.

Como é desafiador oferecer educação de maneira integral, à educação tradicional devem se aliar todos os mecanismos possíveis de serem utilizados em educação. É nesse contexto que o aproveitamento dos meios de educação e de seu poderoso alcance geográfico e social, torna-se de suma importância.

A televisão, ao aliar várias formas de impacto dos sentidos, pode ocupar um papel preponderante nesse cenário, desde que ocorra uma regulamentação correta e apropriada.

\section{Comunicação e mídia}

Percebe-se na história da humanidade o desenvolvimento das comunicações entrelaçado com o desenvolvimento econômico e social (KUNSCH \& FERNANDES, 1989). O homem, ao construir a sociedade, também,constrói formas para comunicar-se de acordo com suas necessidades. É nesse sentido que Kunsch e Fernandes (1998) comentam que as comunicações podem afetar o comportamento coletivo, a partir do momento da difusão da informação, quando as pessoas recebem o que foi transmitido. 
A comunicação pode ser entendida como troca de mensagens entre pessoas em diferentes contextos sociais e espaciais, já que ela traz consigo uma informação (SOUSA, 2003). As trocas de mensagens podem possibilitar às pessoas o conhecimento de algo que elas não vivenciaram. $\mathrm{O}$ outro pode ser um "informante" de algo novo ou não. Nas relações diárias, as pessoas trocam informações (dados, idéias, valores e outros conteúdos), e conversam sobre inúmeros assuntos do cotidiano (SOUSA, 2003).

Segundo Carey (1988; p. 23), pode-se definir comunicação como "um processo simbólico onde a realidade é produzida, mantida, reparada e transformada". Nesse sentido, o autor comenta que a comunicação vai além da transmissão de informações, ela possui um papel social, faz parte das relações pessoais e culturais (CAREY, 1988; MCQUAIL, 2003; THOMPSON, 1998).

De acordo com Wolton (2004; p. 15), que descreve sobre pensar a comunicação, relata “... a informação não cria comunicação. No passado, as mensagens e os receptores eram tão poucos que se podia falar de uma cultura comum. Na maior parte do tempo a informação criava a comunicação". Wolton (2004) ainda comenta que, atualmente, devido à globalização e às novas tecnologias das indústrias culturais e da comunicação, a informação e a comunicação não permanecem no mesmo nível.

Na vida cotidiana é onde circulam as idéias, as pessoas trocam palavras. É essa dinâmica que movimenta a sociedade, e é por essas interações que o homem pode modificar e desenvolver o que é produzido (THOMPSON, 1998). São pelas relações das pessoas com o mundo e o uso de meios para comunicar, que são criadas novas formas de ação e interação. Os meios permitem uma comunicação além do presencial, fazendo com que as pessoas ampliem as possibilidades físicas e topológicas, podendo, assim, estar em lugares distantes umas das outras (MCQUAIL, 2003; SOUSA, 2003; THOMPSON, 1998).

Existem alguns fatores que influenciam o processo de comunicação, pois de acordo com Souza (2003) e Wolton (2004) a percepção do outro (receptor) é um fator limitante à comunicação. A percepção está vinculada a experiências anteriores do sujeito, neste sentido, as mesmas mensagens podem significar coisas diferentes para receptores distintos. “... Não há comunicação sem mal entendidos, sem ambigüidades, sem traduções e adaptações, sem perda de sentidos e surgimento de significados inesperados, enfim, sem fracasso da comunicação e sem regras a satisfazer" (WOLTON, 2004; p. 37).

Há essencialmente, quatro grandes formas de comunicação humana: intrapessoal (comunicação de alguém consigo mesmo, usando frases introspectivas e formas de pensamento automático), interpessoal (comunicação face a face, por exemplo, 
criar e sustentar relações pessoais), organizacional (comunicação - ascendente, descendente e horizontal - no seio de grupos e organizações, como as empresas), mediada (comunicação feita recorrendo a meios de comunicação social) (SOUSA, 2003; p. 14).

A comunicação é algo inerente ao ser humano, pois é necessária para relacionar-se com os outros. As mídias estão presentes na sociedade para aperfeiçoar os processos comunicacionais e não deixar que as pessoas fiquem sem comunicação (NEVES et al., 2007).

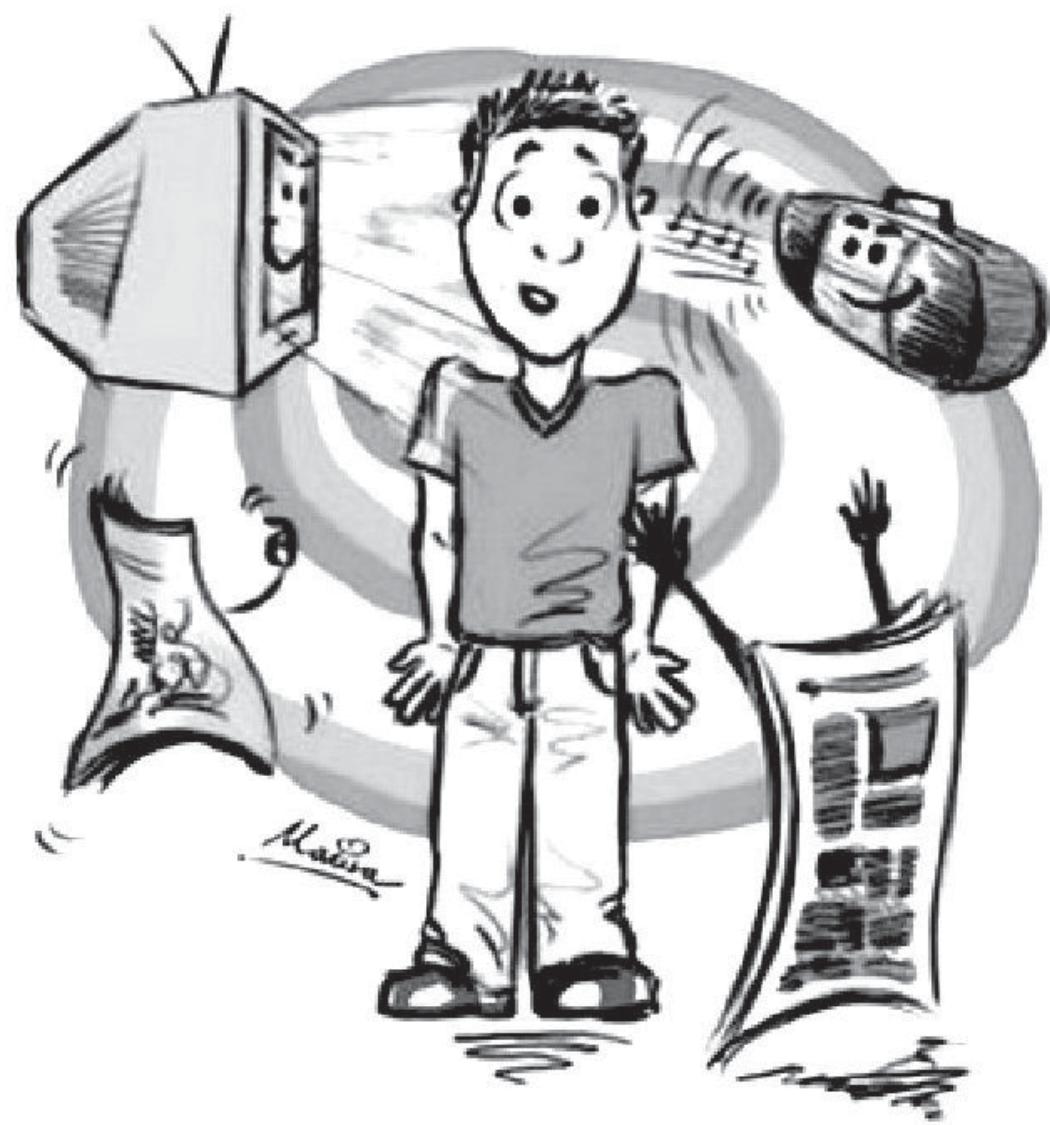

Figura 1

O desenho ilustra o "bombardeio" de informações que as pessoas podem submeter-se, diariamente, por diferentes mídias. 
O foco deste artigo é compreender a comunicação mediada, especificamente, a influência da televisão na educação. Por isso, a partir deste momento, será descrito o que é mídia e quais são os tipos de mídia existentes. Silverstone (2002) comenta que ao falar de mídia é necessário pensar nela como um processo de mediação, que envolve dois ou mais personagens, produtores da mensagem, meio por onde ela passa e o consumidor da mensagem. A mediação também implica movimentos de significados e/ou discursos de um sujeito para outro, pois vivemos no mundo da mídia e da mediação.

A mídia (meio técnico) vem com uma proposta de estabelecer interações entre pessoas através do uso de um meio técnico, sendo que as informações e os conteúdos simbólicos são transmitidos a partir desses meios construídos pelos homens (THOMPSON, 1998). De acordo com Guareschi (2005), os meios de comunicação são considerados mídia. As mídias estão relacionadas com tecnologias que emitem seus conteúdos. Na sociedade, existem diferentes tipo de mídia como, por exemplo, mídia impressa (jornais, revistas, livros, etc.), mídia audiovisual (cinema e televisão), mídia eletrônica ou hipermídia (Internet e TV digital). (MCQUAIL, 2003).

Segundo Guareschi (2005; p. 38), "a mídia é o coração da sociedade de informação, sob cuja égide vivemos. E a informação é o novo modo de desenvolvimento responsável pela produtividade do sistema capitalista dos dias de hoje." Nesse contexto, quem possui a informação - geralmente a mídia possui - é dono desse fator de desenvolvimento humano, pois as pessoas são influenciáveis pela mídia (notícias, novelas e filmes por exemplo) no modo de se relacionar e viver (GUARESCHI, 2005).

Hoje, estamos vivendo na sociedade da aprendizagem e do conhecimento, as novas tecnologias da comunicação e informação estão disponíveis para diminuir distâncias e emitir significados e/ou mensagens (SCHIAVONI, 2007). A mídia está presente na sociedade para suprir as necessidades de comunicação, podendo ser usada em diferentes formas como: informar, entreter e educar (MCQUAIL, 2003).

\section{Educação}

Pode-se entender educação como um processo permanente na vida das pessoas, com suas diferentes práticas e atividades no contexto social (CLAUSSE, 1969; FREIRE, 1997). Freire (1997) ainda comenta que são suas reflexões sobre o ser humano que o fazem entender educação como prática permanente. Segundo Piaget (1985; p. 154), "educar é adaptar o indivíduo ao meio social ambiente." Na frase anterior, o autor refere-se a modificar a constituição psicológica do sujeito de acordo com a sua realidade social. 
De acordo com Guareschi (2005), educação deve ser entendida como algo mais amplo, estando ela presente em diferentes momentos da vida social das pessoas. A educação faz parte do cotidiano, sendo ela importante para a sociedade. "A educação é um ato de amor, por isso, um ato de coragem. Não pode temer o debate, a análise da realidade. Não pode fugir à discussão criadora, sob a pena de ser uma farsa" (FREIRE, 1983; p. 96). Trabalhar com educação é doar um pouco de si para o outro.

Pelo dinamismo e exigências da sociedade, a pessoa deve prosseguir com educação pela vida inteira, pois se isso não acontecer ela será ultrapassada pelo outro que está nesse processo de educação transformação (CLAUSSE, 1969). É pela educação que o sujeito conquista a sua autonomia, consegue libertar-se do outro e vai buscar o conhecimento (FREIRE, 2006). O educador possui um papel importante na formação das pessoas, pois ele pode estimular e administrar a curiosidade por aprender (DIMENSTEIN, 1999, apud NEVES et al., 2007).

Educação fortalece a democracia, pois é pela democratização da educação que atingiremos a democracia e a cidadania (NUNES, 2000; CARVALHO, 2004). A educação pode proporcionar ferramentas às pessoas para que elas possam cultivar suas idéias e pensamentos sobre a realidade social. "Quando a gente compreende educação como possibilidades, a gente descobre que educação tem limites. É exatamente porque é limitável, ou limitada ideológica, econômica, social, política e culturalmente, que ela tem eficácia" (FREIRE, 2006; p. 91).

A educação é desenvolvida dentre as interações sociais da pessoa, é pela relação com o outro que acontece o desenvolvimento mental, ou seja, educação (PIAGET, 1973). A sociologia educacional vem para contribuir com educação. Como destacou Morrish (1975, p.30) "a educação só pode ser entendida quando sabemos para que sociedade e para que posição social os alunos estão sendo educados." A educação é concebida e transmitida dentro da realidade, e o contexto social é relevante para educação, por isso deve-se fazer uma articulação entre o meio social e a educação (MORRISH, 1975).

Educação facilita a inclusão social. A participação da comunidade no processo educar mobiliza a rede social local para incentivar a participação de todos (FREIRE, 1997; MESQUITA, 2008). A educação está presente em diferentes momentos da vida, na família, igreja, empresa, instituições, política e comunidade. Assim, essas instâncias norteiam e instruem como as pessoas devem agir e comportar-se em sociedade (GUARESCHI, 2005).

A educação é um direito de todos, como foi estabelecida na Declaração Universal dos Direitos humanos (1948), por isso, o estado deve ter projetos para garantir o direito à educação pública de qualidade para a população e assim, conquistar sua cidadania (PIAGET, 1973; FREIRE, 1997; NUNES, 2000; CARVALHO, 2004). 
Segundo Pretto e Pinto (2006; p. 23), "pode-se afirmar que a educação, hoje em dia, deve, idealmente, preparar as pessoas para a vida, cidadania e trabalho." Contribuir com a formação social do sujeito, com as práticas do cotidiano das pessoas (FREIRE, 1997). A educação possibilita a formação de seres humanos conscientes, críticos, livres e responsáveis (FREIRE, 1983; GUARESCHI, 2005). Pensar em educação no sentido de reflexão crítica da realidade social (FERRÉS, 1996).

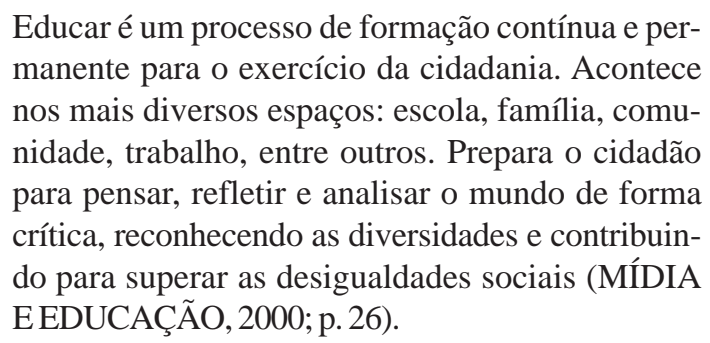

A sociedade precisa superar a tendência tradicional da educação, onde as pessoas são treinadas para legitimar o que existe. Nesse modelo de educação não há consciência de si e do outro, elas deveriam ser educadas para pensar, ter liberdade para escolher que caminho seguir (FREIRE, 1983; GUARESCHI, 2005).

A educação está presente em diferentes momentos da vida cotidiana. Então, faz-se a pergunta para relacioná-la com o tema deste artigo: O que a televisão tem a ver com a educação? Quais são suas contribuições e impactos sobre ela?

Segundo Moran e colaboradores (2000), a mídia também contribui com a educação, e um dos principais meios nesse processo é a televisão. Através da mídia, dispositivos tecnológicos como, por exemplo, a TV, é que são difundidas as mensagens (SOUZA, 2003).

\section{Televisão e educação}

A televisão foi concebida para ser um meio de comunicação audiovisual. Num primeiro momento, foi projetada como um meio de difusão, atualmente, com as novas tecnologias (digitais), foi-se transformando devido aos jogos de vídeos e as possibilidades de interatividade com a internet (MCQUAL, 2003). Seus construtores não definiram qual seria a função da TV na sociedade, eles desenvolveram um artefato de envio e transmissão de sinais (VILCHES, 1996). 


\section{HUMANAS}

De acordo com Souza (2003), "como ocorreu com outras mídias, a televisão não é criação de uma só pessoa. Foram diversas pessoas, descobertas e pesquisas, em momentos diferentes, que contribuíram para sua criação." Ela é fruto de uma investigação técnica e científica (VILCHES, 1996). Souza (2003) ainda comenta que essa jornada iniciou-se em 1817, data do primeiro passo rumo à criação da TV, e pode-se considerar que foi concluída em 1929, quando a BBC de Londres iniciou a difusão, de meia hora por dia, das imagens televisivas. As principais datas são mencionadas a seguir:

1817 - Berzeluis descobriu que a condutibilidade elétrica do selênio aumenta sob ação da luz;

1864 - Maxwell descobriu as ondas eletromagnéticas;

1869 - Hittfort descobriu os raios caóticos, um fenômeno que se produz devido à passagem de eletricidade através de gases raros;

1870 - Hertz produziu as primeiras ondas eletromagnéticas;

1873 - May e Smith estabeleceram a relação que existe entre a resistência elétrica de uma placa de selênio e o grau de iluminação que recebe; 1875 - Carey estuda um sistema, que não chega a construir, baseado na adoção de 2500 células de selênio (emissoras) conectadas a um ecrã receptor integrado por 2500 pequenas lâmpadas elétricas. Estabelece-se pela primeira vez o principio da decomposição da imagem em pontos como base para a sua transmissão;

1875 - Kerr inventa a célula fotoelétrica, que permite transformar as variações de luz em variações de correntes elétrica;

1876 - Bell inventa o telefone (transmissão elétrica de sons);

1877 - Adriano de Paiva, professor da Academia Politécnica do Porto, em Portugal, escreveu um artigo, infelizmente publicado apenas em 1890, onde descreve um método de utilização do selênio para a transmissão de imagens à distância;

1878 - Senlecq projeta um sistema baseado no estudo de Carey, mas de leitura sequiencial da imagem por pontos, em que as 2500 pequenas lâmpadas elétricas se iluminam e apagam sucessivamente com um intervalo de 0,1 segundos;

1884 - Nipkow projeta e patenteia um método mecânico de transmissão de imagens, baseado num disco com orifícios eqüidistantes, dispostos em espiral. A imagem era decomposta em pequenas parcelas, emitida através de um tubo de néon e recebida em células fotoelétricas. Este disco foi posteriormente substituído por um tambor rotativo recoberto de pequenos espelhos que projetavam a imagem num ecrã de selênio;

1890 - Edouard Branly inventa o radiocondutor; 
1894 - Marconi construiu uma antena emissora e um receptor, que tornaram operativo o sistema de Branly; Lee Forest inventou o tríodo, um amplificador que foi primeiro adaptado ao telefone antes de ser usado na rádio e que permitia a transmissão e captação da voz humana;

1897 - Braun constrói um tubo de raios caóticos conjugados com um ecrâ fluorescente;

1906 - Dieckmann e Glage fizeram uma transmissão televisiva de imagens aplicando o sistema de Braun a um sistema telegráfico;

1923 - Zworykin, partindo do tubo de raios caóticos, inventa o iconoscópio, onde a imagem é formada num mosaico fotossensível varrido linha a linha por um canhão eletrônico;

1926 - Baird aplica o disco de Nipkow a uma transmissão televisiva com uma definição de trinta linhas a 20 quilômetros de distancia. Mas este era um processo mecânico de televisão, que veio a ser preterido em favor do processo eletrônico de Zworykin;

1927 - a Bell Company usa o iconoscópio de Zworykin para transmitir imagens a 45 quilômetros de distância.

1929 - como se referiu, a BBC inicia as emissões regulares de televisão (SOUZA, 2003, p.346).

Foi no século XX que a televisão, o rádio e o telefone tornaram-se artefatos de "consumo de massa", altamente utilizados e fundamentais para os seres humanos (SILVERSTONE, 2002). As pessoas passaram a consumir televisão diariamente. A televisão ocupou um papel importante no seio familiar, muitas atividades cotidianas são organizadas de acordo com a programação da emissora de TV (FERRÉS, 1996).

A televisão, assim como o cinema, consegue retratar na tela diferentes coisas acontecendo simultaneamente, diferente do rádio e da escrita, que se limitam a descrever uma coisa de cada vez (GREEFIELD, 1988). Talvez a possibilidade de estímulo de mais de um sensório (visão e audição) simultaneamente possa ser o motivo que fez com que a televisão tenha encantado tantas pessoas no mundo, desde sua popularização. A televisão "resume em si três dimensões que se complementam: imagem, que é o principal, o som e o texto... é, hoje, o meio de comunicação central, hegemônico, o mais assistido" (GUARESCHI, 2005; p. 180).

Segundo Moreira (2003), as imagens e sons que a televisão proporciona, fazem o sujeito mergulhar num mundo permeado por fantasias e desejos, a pessoa fica envolvida nas sensações de desafios que são transmitidos na tela. Ao ligar e desligar a televisão, a pessoa está conectando-se e desconectando-se com a mídia, mais precisamente, com o produto e os efeitos da mídia (SILVERSTONE, 2002). Um grande número de pessoas que está na frente da TV vê pessoas, 
ações, eventos e informes publicitários, mas aquele que transmite as informações não tem a possibilidade de ver aqueles que o estão vendo (THOMPSON, 1998).

\begin{abstract}
$\mathrm{E}$, insensivelmente, a televisão que se pretende um instrumento de registro torna-se um instrumento de criação da realidade. Caminha-se cada vez mais rumo a universos em que o mundo social é descrito/prescrito pela televisão. A televisão se torna árbitro do acesso à existência social e política (BORDIEU, 1997; p. 29).
\end{abstract}

Pela televisão são passados diferentes conceitos e ideologias, e essa é uma problemática a ser estudada, pois é preciso compreender que informações estão sendo transmitidas (GUARESCHI, 2005; KUNSCH \& FERNANDES, 1989). "No entanto, a televisão, que se tornou o fenômeno cultural mais impressionante da história da humanidade, é a prática para a qual os cidadãos estão menos preparados" (FERRÉS, 1996; p. 9).

Atualmente, a TV é o aparelho mais encontrado nas casas dos brasileiros, ultrapassando o rádio. Segundo indicadores do IBGE (2006 e 2007), 93\% dos domicílios brasileiros possuem televisão, número de aparelhos superior ao rádio, com 87,9\% dos domicílios. Anteriormente, o Censo Demográfico de 2002 constatou que $87,4 \%$ dos lares possuíam rádios e $87 \%$ possuíam televisão, para recordar que $82 \%$ dos lares possuem geladeira (GUARESCHI, 2005). Podese perceber a importância da TV para as pessoas no Brasil.

Esse instrumento de difusão conquistou um espaço privilegiado na sociedade, na cultura e idéias das pessoas (FERRÉS, 1996). A média de horas nas quais o brasileiro adulto assiste TV é de quatro horas, enquanto que, para crianças, a média é de seis horas. Porém, para crianças cujos pais preferem que elas fiquem dentro de suas casas, por medo que elas fiquem brincando na rua, a média é de nove horas por dia (GUARESCHI, 2005).

As pessoas sentem prazer em assistir televisão, pois há uma relação de sedução entre a TV e o telespectador. Poder emocionar-se e ter experiências diferentes do cotidiano encanta as pessoas (MORAN et al., 2000). Essa relação pode ser usada a favor da educação, porém como observações negativas sobre a TV já foram difundidas, deve-se pensar em tornar esse aparelho em recurso construtivo para a vida das pessoas (GREENFIELD, 1988).

A televisão produz efeitos sobre a aprendizagem, de acordo com alguns condicionantes da programação apresentada e da recepção do sujeito. As crianças são telespectadoras ativas e por isso são capazes de desenvolver habilidades cognitivas ao interagir com a televisão (FERRÉS, 1996; VILCHES, 1996). 
Programas educativos na TV podem auxiliar no desenvolvimento cognitivo e na aprendizagem. Usados de forma adequada, os meios de comunicação podem contribuir com o desenvolvimento intelectual humano (FERRÉS, 1996; GREENFIELD, 1988).

Os programas televisivos contam histórias fictícias com base na realidade humana. Alguns personagens são considerados "bons" e outros "maus", pelo público, tornando-se referências que as pessoas, ao assistirem, trazem para sua vida cotidiana, fazendo com que crianças e adultos tenham como modelo as pessoas e suas atitudes (CARLSSON \& FEILITZEN, 2002). Esses modelos comportamentais expostos na tela são copiados no cotidiano pela população, por isso, os idealizadores dos programas deveriam cuidar dos conteúdos que eles estão transmitindo (GUARESCHI, 2005).

Assistir televisão muda os sentidos das pessoas. A percepção e a atenção transformam-se devido à hiperestimulação sensorial oriunda das cores, movimentos e mudanças de câmeras (FERRÉS, 1996). A possibilidade de combinação e articulação estática ou dinâmica de imagem, música, fala e escrita, ao vivo ou gravado, consegue encantar, entreter e desenvolver cognitivamente as pessoas (MORAN et al., 2000). A eficácia emocional das imagens aumenta com o seu grau de iconicidade, mas em geral não se dispensa o texto ou a fala (MOREIRA, 2003). A articulação entre o texto e a fala é que favorece a eficácia emocional da imagem.

Assistir televisão exige que a pessoa aprenda a decodificar os símbolos que são expressos na tela. Programas semelhantes à Vila Sésamo, série televisiva infantil da década de 70, com seus recursos e conteúdos, podem ajudar crianças a desenvolver aspectos da cognição (GREEFIELD, 1988).

Diferentes conteúdos podem ser exibidos e, nessa era de globalização, as informações chegam em tempo real em qualquer parte do mundo (MCQUAIL, 2003; SILVERSTONE, 2002). Nesse contexto, onde as pessoas não analisam o que assistem, e não percebem o que é realidade e o que é verdade, passam a acreditar no que está sendo transmitido (GUARESCHI, 2005).

Como as pessoas de nossa sociedade, desde a infância, relacionam-se com os meios de comunicação, estes exercem uma função pedagógica como (des)educador das massas e das crianças (MOREIRA, 2003). A sociedade poderia pensar em uma educação para as mídias, para poder compreendê-las, analisá-las, criticá-las e usá-las de maneira mais abrangente e consciente (GUARESCHI, 2005; MORAN et al., 2000).

De acordo com Wolton (2004), uma parcela da sociedade condena o papel da televisão na cultura, o poder público é conivente com o privado, e as empresas de TV não cumprem o seu papel social e de valorização da cultura nacional. Com uma sociedade engajada na discussão do papel social e cultural da mídia, poderse-ia ter uma mídia mais democrática e participativa (GUARESCHI, 2005). 
É nesse sentido que Silverstone (2002) e Guareschi (2005) comentam que é preciso educar e formar cidadãos críticos e conscientes, que criem o Quinto Poder com o objetivo de desafiar, criticar e controlar o Quarto Poder (Mídia), pois até o momento ele está dominando os outros três poderes (Legislativo, Executivo e Judiciário).

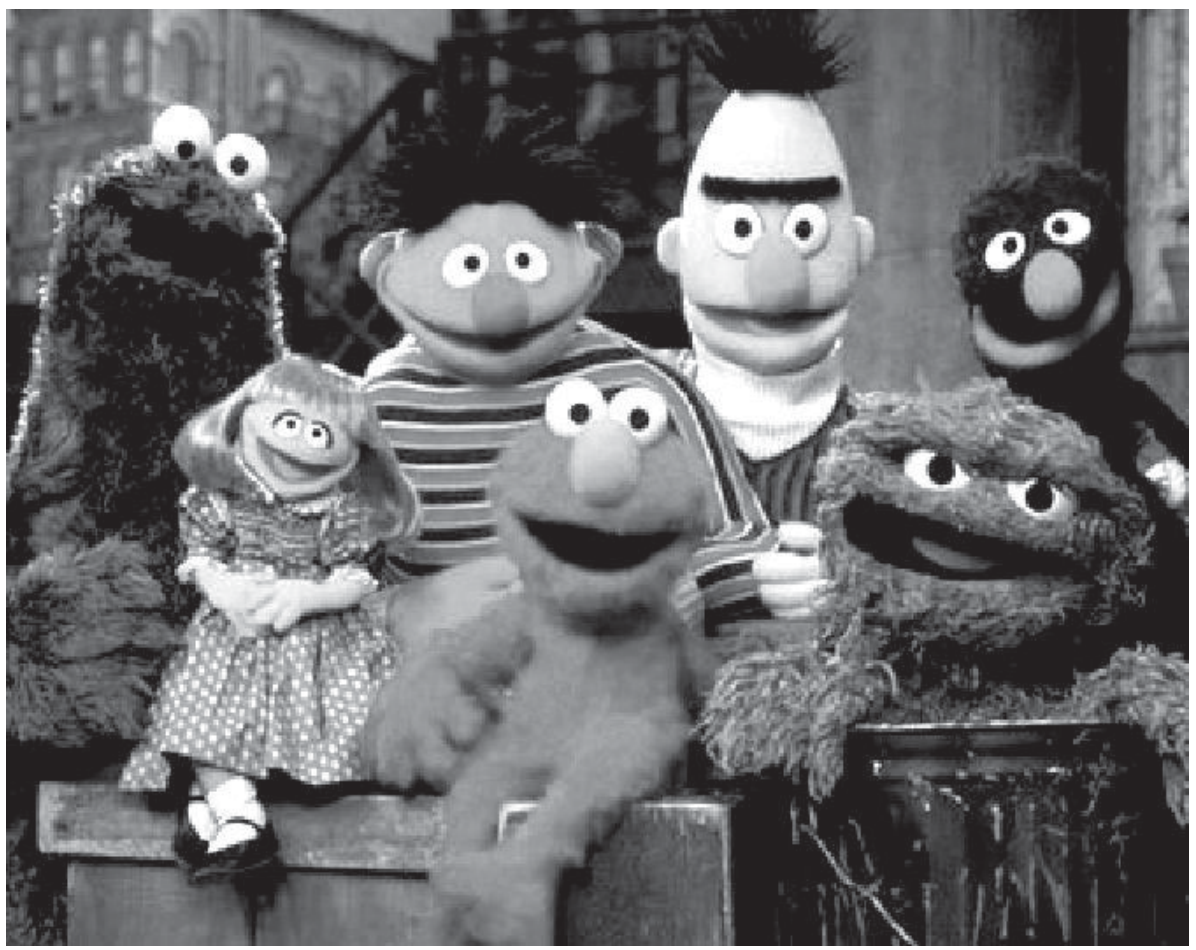

Figura 2

Vila Sésamo, programa infantil da década de 70, cujo objetivo era desenvolver alguns aspectos cognitivos das crianças.

Sobre memória e aprendizagem, identificou-se que as crianças, ao assistirem televisão, acreditam que podem superar-se. Aspectos cognitivos são estimulados pela TV, porém nem todos os programas que são transmitidos possuem conteúdos relevantes para a sociedade, nos quais poderiam ser abordados informações educacionais e/ou culturais (VILCHES, 1996).

As empresas de televisão, para manter-se e manter no ar os seus programas, precisam da entrada de recursos financeiros. Para isso, elas vendem espaço de tempo para que outras empresas divulguem seus produtos e, assim, os programas ficam impregnados de valores de consumismo, devido aos patrocinadores e suas propagandas (FERRÉS, 1996; THOMPSON, 1998; GUARESCHI, 2005). A principal fonte de recurso da mídia é a publicidade, 
e pode-se dizer que ela é o "patrão" da empresa. A obtenção de lucro torna-se o primeiro mandamento, os programas educativos cujo faturamento não satisfaz são secundários ou suprimidos da grade de programação (FERRÉS, 1996; GUARESCHI, 2005).

Certa vez Theodor Adorno (1954), citando Leo Lowenthal, descreveu a televisão como psicanálise ao inverso, sugerindo, ou assim me parece, a capacidade do médium de construir, em vez de desconstruir, as camadas do inconsciente e reproduzir sedutoramente em seus programas o mascaramento e o espelhamento da mente. Meu argumento defende a idéia que a mídia - sobretudo cinema, televisão e rádio poderia ser descrita igualmente bem (ou mal) como história ao inverso. Ela produz os textos para a imaginação popular, igualmente provida de camadas e igualmente sugestiva (SILVERSTONE, 2002; p.245).

A televisão é uma ferramenta que poderia ser usada para auxiliar o educador a explorar, e desenvolver, atividades pedagógicas em sala de aula. $\mathrm{Na}$ tela, poder-se-ia fazer recortes de novelas, filmes e outros programas do cotidiano das pessoas e analisá-los em conjunto. Trabalhar com TV, para os alunos, significaria descanso e não aula (MORAN et al., 2000).

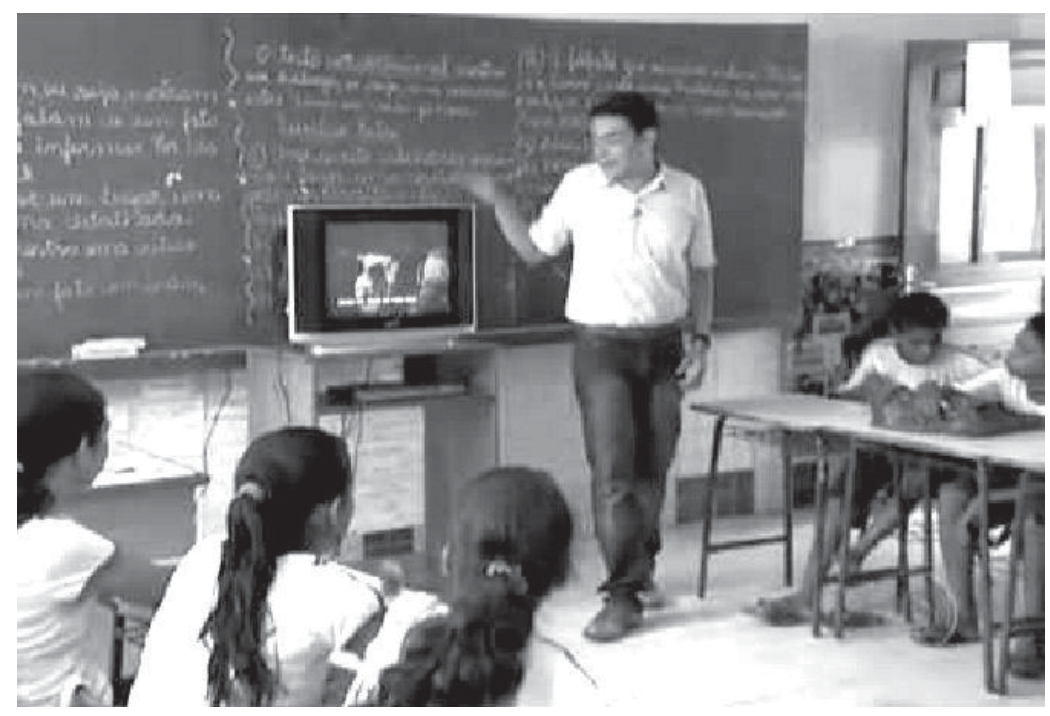

Figura 3

Uso da televisão em sala de aula para contribuir com a construção de novos conhecimentos. 


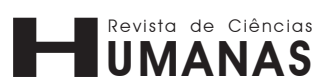

Segundo Ferrés (1996), a televisão produz sensação de gratificação sensorial, mental e psíquica. A gratificação sensorial oriunda dos estímulos visuais (luzes, formas e cores) e sonoros (músicas e sons), além dos belos e sedutores personagens, cenários fascinantes, objetos de desejo e boa comida. A gratificação mental proveniente das fábulas que são apresentadas, que estimulam a imaginação e complementam o mundo real. A gratificação psíquica derivada da libertação catártica desencadeada pelos processos mentais inconscientes de identificação e projeção.

A televisão exibe diferentes programas com conteúdos distintos, uns para adultos e outros para crianças. Existe a possibilidade de aprendizado com a TV, mas, para que isso ocorra, dependerá da escolha do programa. Os adultos deveriam apresentar às crianças os programas educacionais infantis e não permitir que ela assista, por muito tempo, aos programas destinados aos adultos (GREENFIELD, 1988).

Em toda mídia pode-se veicular ideologia, e com a televisão não é diferente, pois podem-se "usar formas simbólicas para criar ou reproduzir relações de dominação" (GUARESCHI, 2005; SOUZA, 2003). Os conteúdos expressos são carregados de ideologia e valor, já que ao analisar e entender as mensagens, percebe-se o incentivo ao consumo, representações de gênero e autoridade (CARLSSON \& FEILITZEN, 2002).

A escola de Frankfurt criticou a forma como os meios de comunicação usam estratégias para exercer o seu poder e dominação, "as pessoas tendem a aderir acriticamente a valores que lhe são impostos pela força da indústria cultural, não exprimindo o que pensam, mas sim o que a indústria cultural quer que eles pensem" (SOUZA, 2003; p. 240).

Os grupos organizados de oposição são importantes para pressionar a mídia. A pressão é realizada para conquistar democratização e participação na mídia. "A forma mais comum é a pressão sobre os anunciantes para que retirem seus patrocínios" (GUARESCHI, 2005; p. 164). As empresas de televisão ganham dinheiro com a publicidade, então a população deveria tentar mobilizar as empresas anunciantes para a democratização da mídia, ampliação e melhoria dos programas educativos.

Seria errôneo afirmar que a televisão teria somente efeitos maléficos à população, pois diferentes conteúdos são expressos. Há manipulação na TV, porém há aprendizagem e formação, já que o cérebro recebe estímulos sensoriais benéficos ao desenvolvimento cognitivo. A televisão é um artefato da comunicação, um meio, não pode ser considerada nem boa nem má (VILCHES, 1996). A maldade e a bondade estão presentes nos seres humanos, no olhar, na fala e no ouvido e não nos objetos. 


\section{Considerações finais}

É inegável que a estrutura já desenvolvida pela televisão com o meio de transmissão de informações deve ser estabelecida como ferramenta do processo educacional, pelos diversos motivos citados nesse trabalho.

Para tanto, algumas questões devem ser trabalhadas por todos os envolvidos, sejam produtores de TV, entidades reguladoras, publicitários, agentes públicos, educadores e a sociedade em geral.

A TV, como tecnologia, não produz efeito nenhum sobre a sociedade. São os conteúdos veiculados por ela que podem produzir impactos negativos ou positivos. Sendo assim, se houver um foco na qualidade desses conteúdos, seja pelo correto comprometimento de quem produz ou pelo controle dos próprios usuários, surge um grande terreno educacional a ser utilizado.

No momento que as pessoas se conscientizarem dos cuidados em tratar as informações recebidas pela televisão, fazendo um julgamento crítico daquilo que lhe é transmitido, naturalmente passarão a exigir mais qualidade. $\mathrm{O}$ uso indiscriminado da televisão em detrimento de outras formas de lazer também se constitui um obstáculo no caminho de se produzir um caminho voltado para a educação, pois o que pode mudar a mentalidade dos consumidores desse meio é a diversidade de informações e conteúdos. Por isso, o uso excessivo desse veículo de comunicação é, sem dúvida, prejudicial.

Como o problema educacional é grande em nosso país, decorrente de seguidas políticas públicas ineficientes, não se pode esperar que a sociedade atinja esse nível crítico naturalmente. É necessário que os entes reguladores do sistema e os agentes educacionais criem uma política conjunta de aprimoramento desse sistema, dando maior ênfase educacional.

Não pode haver ilusão de que seja tarefa simples, pois enquanto os recursos que movem a estrutura da televisão forem oriundos, prioritariamente, dos agentes de publicidade, que representam os donos do capital, teremos um grande obstáculo pela frente. Será preciso que a busca pelo crescimento educacional da sociedade consiga se impor, de alguma forma, sobre a busca pelo lucro fácil que, paradoxalmente, alimenta-se da própria deficiência educacional.

\section{Referências bibliográficas}

BORDIEU, P. Sobre a televisão. Rio de Janeiro: Zahar, 1997.

CAREY, J.W. Communication as culture: essays on media and society. Boston: Unwin Hyman, 1988.

CARLSSON, U. \& von FEILITZEN, . C. (Orgs.). A criança e a mídia: imagem, educação, participação. São Paulo: Editora Cortez, 2002. 
CARVALHO, J.S. Formação de professores e educação em direitos humanos e cidadania: dos conceitos às ações. Educação e pesquisa, 30 (3): 435-45, 2004.

CLAUSSE, A. Iniciação às ciências da educação. Trad. L.D. Penna \& J. B. Penna. São Paulo: Editora Nacional, 1969.

DECLARAÇÃO UNIVERSAL DOS DIREITOS HUMANOS, de 10 de dezembro de 1948.

FERRÉS, J. Televisão e educação. Trad. B.A. Neves. Porto Alegre: Artes Médicas, 1996.

FREIRE, P. Educação como prática de liberdade. $14^{a}$ Edição. Rio de Janeiro: Editora Paz e terra, 1983.

FREIRE, P. Política e educação. $3^{\text {a }}$ Edição, volume 23. São Paulo: Editora Cortez, 1997.

FREIRE, P. A educação na cidade. $7^{\text {a }}$ Edição. São Paulo: Editora Cortez, 2006.

GREENFIELD, P.M. O desenvolvimento do raciocínio na era da eletrônica: os efeitos da TV, computadores e videogames. Trad. C. Bonamine. São Paulo: Editora Summus, 1988.

GUARESCHI, P.A. Mídia, educação e cidadania: tudo o que você deve saber sobre a mídia. $2^{\mathrm{a}}$ Edição. Petrópolis: Editora Vozes, 2005.

IBGE Instituto Brasileiro de Geografia e Estatística. Tabelas de resultados Parte A - Indicadores de 2006 e 2007. Disponível em: <http://www.ibge.gov.br/ home/estatistica/populacao/trabalhoerendimento/pnad2007/sintese/tab6_1.pdf $>$. Acesso em 28 jun. 2009.

KUNSCH, M.M.K. \& FERNANDES, F.A.M. (Orgs.). Comunicação, democracia e cultura. São Paulo: Edições Loyola, 1989.

MCQUAIL, D. Teoria da comunicação de massas. Trad. C. de Jesus. Lisboa: Fundação Calouste Gulbenkian, 2003.

MESQUITA, R.B. et al . Análise de redes sociais informais: aplicação na realidade da escola inclusiva. Interface - Comunicação, Saúde, Educação, 12 (26): 549-62, 2008.

MÍDIAEEDUCAÇÃO: perspectiva para a qualidade da informação. Brasília, 2000.

MORAN, J.M.; MASETTO, M.T. \& BEHRENS, M.A. Novas tecnologias e mediação pedagógica. $5^{\text {a }}$ Edição. Campinas: Editora Papirus, 2000. 
MOREIRA, A.S. Cultura midiática e educação infantil. Educação e sociedade, 24 (85): 1203-35, 2003.

MORRISH, I. Sociologia da educação: uma introdução. Trad. A. Cabral. $2^{\mathrm{a}}$ Edição. Rio de Janeiro: Editora Zahar, 1975.

NEVES, F.F.R.; LEITE,I.DA.; BRAMBILLA, M.A. \& ACCARDO, R.P. In: Anais do CONGRESSO BRASILEIRO DE CIÊNCIAS DA COMUNICAÇÃO, Santos/SP, 2007.

NUNES, C. Anísio Teixeira entre nós: a defesa da educação como direito de todos. Educação e sociedade, 21 (73): 9-40, 2000.

PIAGET, J. Para onde vai a educação? Trad. I. Braga. Rio de Janeiro: Livraria José Olympio, 1973.

PIAGET, J. Psicologia e pedagogia. Trad. D.A. Lindoso \& R.M.R. da Silva. $7^{\text {a }}$ Edição. Rio de Janeiro: Editora Forense Universitária, 1985.

PRETTO, N. \& PINTO, C.C. Tecnologias e novas educações. Revista Brasileira de Educação, 11(31): 19-30, 2006.

SCHIAVONI, J.E. Mídia: o papel das novas tecnologias na sociedade do conhecimento. Diversidade e igualdade na comunicação. Bauru/SP, 2007. Disponível em: 〈www.faac.unesp.br/publicacoes/anais-comunicacao/textos/01.pdf〉. Acesso em: 20 mai. 2009.

SILVERSTONE, R. Por que estudar a mídia? São Paulo: Edições Loyola, 2002.

SOUSA, J.P. Elementos de teoria e pesquisa da comunicação e da mídia. Porto: Edições Universidade Fernando Pessoa, 2003.

THOMPSON, J.B. A mídia e a modernidade: uma teoria social. Trad. W.O. Brandão. Petrópolis: Editora Vozes, 1998.

VILCHES, L. La televisión los efectos del bien y del mal. Barcelona: Paidós Comunicación, 1996.

WOLTON, D. Pensar a comunicação. Trad. Z.L. Adghirni. Brasília: Editora Universidade de Brasília, 2004. 